\title{
PENERAPAN ANALISIS CLUSTER ENSEMBLE UNTUK MENGELOMPOKKAN PROVINSI DI INDONESIA BERDASARKAN INDIKATOR KESEHATAN LINGKUNGAN
}

\author{
YULIZA DIANA PUTRI, IZZATI RAHMI HG, HAZMIRA YOZZA \\ Program Studi S1 Matematika, \\ Fakultas Matematika dan Ilmu Pengetahuan Alam, Universitas Andalas, \\ Kampus UNAND Limau Manis Padang, Indonesia, \\ email: yulizadianaputrii@gmail.com
}

Diterima 9 Maret 2019 Direvisi 7 April 2019 Dipublikasikan 7 Mei 2019

\begin{abstract}
Abstrak. Kesehatan lingkungan merupakan bagian dari pada kesehatan masyarakat pada umumnya. Setiap daerah memiliki keadaan kesehatan lingkungan yang berbedabeda jika dikaitkan dengan indikator kesehatan lingkungan tersebut. Oleh karena itu prioritas program penyehatan lingkungan pun berbeda pada setiap daerah. Suatu hal yang menarik untuk diketahui adalah bagaimana kesamaan/kemiripan dari masingmasing daerah tersebut berdasarkan indikator kesehatan lingkungan. Kemiripan tersebut selanjutnya dapat dijadikan dasar untuk melakukan pengelompokan daerah-daerah tersebut, sehingga daerah yang memiliki kondisi kesehatan lingkungan yang hampir sama akan berada pada satu kelompok dan sebaliknya, daerah-daerah dengan kondisi kesehatan lingkungan yang tidak sama akan berada pada kelompok yang berbeda. Dengan adanya pengelompokan tersebut akan mempermudah pemerintah untuk menentukan prioritas bagi pembangunan kesehatan lingkungan di daerah-daerah tersebut. Dalam penelitian ini metode cluster ensemble akan diterapkan untuk mengelompokkan provinsi di Indonesia berdasarkan 8 indikator kesehatan lingkungan. Penelitian ini menghasilkan solusi pengklasteran terbaik yaitu solusi dengan 2 cluster, dimana anggota dari cluster 1 merupakan provinsi dengan lingkungan sehat yang lebih baik dibandingkan anggota dari cluster 2 .
\end{abstract}

Kata Kunci: Cluster Ensemble, Cluster Hierarki, k-Means Cluster

\section{Pendahuluan}

Lingkungan memiliki peranan yang sangat penting dalam mewujudkan derajat kesehatan masyarakat yang optimal, disamping faktor-faktor lain seperti kualitas pelayanan kesehatan dan perilaku masyarakat. Kesehatan lingkungan merupakan bagian dari pada kesehatan masyarakat pada umumnya. Menyadari pentingnya kesehatan lingkungan diperlukan program-program penyehatan lingkungan yang tujuannya adalah untuk membina dan mempercepat terwujudnya derajat kesehatan masyarakat yang optimal, baik fisik, mental, maupun sosial.

Setiap daerah memiliki keadaan kesehatan lingkungan yang berbeda-beda jika dikaitkan dengan indikator kesehatan lingkungan tersebut. Oleh karena itu priori- 
tas program penyehatan lingkungan pun berbeda pada setiap daerah. Suatu hal yang menarik untuk diketahui adalah bagaimana kesamaan/kemiripan dari masingmasing daerah tersebut berdasarkan indikator kesehatan lingkungan. Kemiripan tersebut selanjutnya dapat dijadikan dasar untuk melakukan pengelompokan daerah daerah tersebut, sehingga daerah yang memiliki kondisi kesehatan lingkungan yang hampir sama akan berada pada satu kelompok dan sebaliknya, daerah-daerah dengan kondisi kesehatan lingkungan yang tidak sama akan berada pada kelompok yang berbeda. Dengan adanya pengelompokan tersebut akan mempermudah pemerintah untuk menentukan prioritas bagi pembangunan kesehatan lingkungan di daerah-daerah tersebut.

Analisis statistika untuk mengelompokkan objek-objek adalah analisis cluster. Analisis cluster saat ini semakin berkembang pesat seiring dengan kemajuan teknologi dan informasi yang melahirkan data besar (big data). Banyak metode cluster yang telah dikembangkan oleh para pakar dan telah banyak pula diterapkan pada berbagai bidang. Selain metode konvensional, yaitu analisis cluster berhirarki dan tak berhirarki, salah satu metode yang hingga saat ini banyak dikembangkan adalah metode cluster ensemble. Metode ini diperkenalkan oleh Strehl dan Gosh pada tahun 2002 [9]. Ide dasar dari cluster ensemble adalah mengombinasikan sekumpulan hasil cluster yang dibentuk berdasarkan metode-metode yang biasa dilakukan. Menurut [9], cluster ensemble dapat memberikan hasil pengklasteran yang lebih berkualitas.

Berdasarkan uraian tersebut, penelitian ini bertujuan menerapkan metode cluster ensemble untuk mengelompokkan provinsi di Indonesia berdasarkan indikator kesehatan lingkungan tahun 2016.

\section{Landasan Teori}

\subsection{Analisis Cluster}

Analisis cluster merupakan metode dengan analisis peubah ganda untuk mengelompokkan n objek ke dalam m cluster $(m<n)$ berdasarkan karakteristiknya. Pengelompokan dilakukan berdasarkan pada sifat kemiripan atau sifat ketidakmiripan antar objek. Objek yang berada dalam kelompok yang sama akan lebih mirip dibandingkan dengan objek pada kelompok yang berbeda.

\subsubsection{Konsep Jarak}

Dalam analisis cluster, objek dikelompokkan berdasarkan kemiripan atau ketidakmiripan antar objek. Salah satu ukuran ketidakmiripan yang paling sering digunakan adalah ukuran jarak dan ukuran jarak yang sering digunakan sebagai ukuran ketidakmiripan antar objek adalah jarak euclid. Penggunaan jarak euclid dilakukan jika tidak ada kerelasi antar peubah. Jarak ini didefinisikan sebagai berikut:

$$
d_{i j}=\left[\left(\mathbf{x}_{\mathbf{i}}-\mathbf{x}_{\mathbf{j}}\right)^{T}\left(\mathbf{x}_{\mathbf{i}}-\mathbf{x}_{\mathbf{j}}\right)\right]^{1 / 2}
$$

Jika satuan pengukuran data tidak sama, maka data perlu ditransformasi ke bentuk baku (Z) sebelum dilakukan perhitungan jarak euclid. Jarak mahalanobis juga dapat digunakan untuk mengatasi korelasi antar peubah. Jarak mahalanobis dihitung 
dengan rumus berikut:

$$
d_{i j}=\left[\left(\mathbf{x}_{\mathbf{i}}-\mathbf{x}_{\mathbf{j}}\right)^{T} \mathbf{S}^{-\mathbf{1}}\left(\mathbf{x}_{\mathbf{i}}-\mathbf{x}_{\mathbf{j}}\right)\right]^{1 / 2}
$$

\subsubsection{Metode Berhirarki}

Metode berhirarki biasanya digunakan jika peneliti belum mengetahui banyaknya cluster yang akan dibentuk dan ukuran contoh relatif kecil. Terdapat dua prosedur pada metode berhirarki ini yaitu agglomerative hieararchical clustering dan divisive hierarchical clustering. Dalam metode agglomerative terdapat lima metode perbaikan jarak yang dapat digunakan.

(a) Pautan Tunggal.

Jarak dua cluster diukur dengan jarak terdekat antara sebuah objek dalam cluster yang satu dengan sebuah objek dalam cluster yang lain.

$$
d_{(u v) w}=\min \left(d_{u w}, d_{v w}\right) .
$$

(b) Pautan Lengkap.

Jarak dua cluster diukur dengan jarak terjauh antara sebuah objek dalam cluster yang satu dengan sebuah objek dalam cluster yang lain.

$$
d_{(u v) w}=\max \left(d_{u w}, d_{v w}\right) .
$$

(c) Pautan Centroid.

Jarak antara dua buah cluster diukur sebagai jarak Euclidian antara kedua rataan (centroid) cluster.

$$
d_{(u v) w}=\frac{n_{u} d_{u w}+n_{v} d_{v w}}{n_{u}+n_{v}}-\frac{n_{u} n_{v} d_{u v}}{\left(n_{u}+n_{v}\right)^{2}} .
$$

(d) Pautan Rataan.

Jarak antara dua cluster diukur dengan jarak rataan antara sebuah objek dalam cluster yang satu dengan sebuah objek dalam cluster yang lain.

$$
d_{(u v) w}=\frac{n_{u} d_{u w}+n_{v} d_{v w}}{n_{u}+n_{v}} .
$$

(e) Pautan Ward.

Jarak antara dua buah cluster sebagai jarak antar median, dan cluster-cluster dengan jarak terkecil akan digabungkan.

$$
d_{(u v) w}=\frac{1}{2} d_{u w}+\frac{1}{2} d_{v w}-\frac{1}{4} d_{u v} .
$$

\subsubsection{Metode Tak Berhirarki}

Metode tak berhirarki digunakan untuk pengelompokan objek dimana banyaknya cluster yang akan dibentuk dapat ditentukan terlebih dahulu sebagai bagian dari prosedur pengklasteran. Metode ini dapat diterapkan pada data yang lebih besar dibandingkan metode hirarki. Metode tak berhirarki yang umum digunakan adalah $k$-rataan ( $k$-means).

Secara ringkas, langkah-langkah pengklasteran menggunakan metode tak berhirarki adalah sebagai berikut [2]: 
(1) Bagi objek-objek tersebut ke dalam $K$ cluster awal.

(2) Masukkan tiap objek ke suatu cluster berdasarkan rataan terdekat. Jarak biasanya ditentukan dengan menggunakan Euclidean. Hitung kembali rataan untuk cluster yang mendapat objek dan yang kehilangan objek.

(3) Ulangi langkah 2 sampai tidak ada lagi pemindahan objek antar cluster.

\subsection{Cluster Ensemble}

Cluster Ensemble diperkenalkan oleh Strehl dan Gosh (2002), yaitu sebuah metode yang digunakan untuk mengombinasikan sekumpulan solusi cluster. Metode ini memiliki keunggulan dibanding metode pengklasteran lainnya, yakni mampu meningkatkan kualitas dan kekekaran solusi cluster [9]. Secara umum, pengklasteran objek dengan metode cluster ensemble dilakukan dalam dua tahap menurut [1], yaitu:

(1) Membentuk anggota ensemble yang anggotanya adalah solusi dari berbagai metode pengklasteran yang berbeda.

(2) Mengombinasikan seluruh anggota ensemble untuk memperoleh satu solusi akhir yang dinamakan solusi Consensus.

Fungsi Consensus didefinisikan sebagai fungsi yang memetakan sekumpulan solusi cluster menjadi solusi gabungan hingga diperoleh satu hasil pengklasteran akhir yang disebut solusi consensus. Fungsi ini memiliki beragam algoritma, salah satunya algoritma Meta-Clustering.

Berikut ini adalah algoritma meta-clustering yang dikembangkan oleh [5]:

(1) Mentransformasi sekumpulan solusi cluster atau anggota ensemble menjadi sebuah matriks indikator. Matriks indikator adalah matriks yang kolom-kolomnya menggambarkan cluster dari setiap solusi sedangkan baris-baris matriks indikator menggambarkan objek pengamatan. Matriks ini terdiri dari angka biner 1 dan 0. Objek bernilai 1 pada kolom tertentu jika merupakan angka cluster yang bersesuaian dengan kolom tersebut dan bernilai 0 jika sebaliknya.

(2) Mengelompokkan kembali objek pengamatan dengan menganggap kolom-kolom matriks indikator sebagai peubah baru yang digunakan dalam analisis cluster. Tahap ini disebut dengan clustering on cluster (CC). Tahap clustering on cluster (CC) menggunakan metode $k$-means sebagai analisis cluster. Pengklasteran pada tahap ini dilakukan secara berulang dengan inisialisasi acak. Pengulangan ini dilakukan untuk mengatasi adanya pengaruh inisialisasi yang berbeda terhadap solusi yang dihasilkan. Kedua langkah di atas dilakukan berulang kali hingga tidak terjadi perubahan keanggotaan cluster yang dihasilkan.

Algoritma Meta-clustering dilakukan secara terpisah untuk kumpulan solusi yang menghasilkan 2, 3, dan 4 cluster.

\subsubsection{Nilai Reproducibility}

Nilai reproducibility untuk membandingkan solusi cluster yang menghasilkan jumlah cluster yang sama dapat diperoleh dengan cara berikut: 
(1) Membuat tabulasi silang solusi cluster ke-i dengan solusi cluster ke-j untuk $i \neq j$. Misalkan terdapat dua solusi yang sama-sama menghasilkan 3 cluster. Tabulasi silang dapat dilihat sebagai berikut:

Tabel 1. Tabulasi Silang Solusi Cluster

\begin{tabular}{|c|c|c|c|c|}
\hline Solusi 1,2 & cluster 1 & cluster 2 & cluster 3 & Total \\
\hline cluster 1 & 0 & 3 & 0 & 3 \\
\hline cluster 2 & 0 & 0 & 2 & 2 \\
\hline cluster 3 & 2 & 0 & 0 & 2 \\
\hline Total & 2 & 3 & 2 & 7 \\
\hline
\end{tabular}

Misal solusi cluster 1 dan solusi cluster 2 yang menghasilkan solusi yang sama namun tampak berbeda. Perbedaan tersebut menimbulkan masalah ketika dilakukan tabulasi silang antar solusi sehingga mempengaruhi nilai reproducibility. Untuk mengatasi hal tersebut perlu dilakukan penukaran posisi kolom ke posisi yang bersesuaian dengan posisis baris yang mempunyai nilai terbesar pada kolom tersebut sehingga dapat memaksimalkan jumlah diagonal. Setelah dilakukan penukaran posisi kolom maka tabulasi silang antara solusi cluster 1 dan solusi cluster 2 berubah seperti Tabel 2 .

Tabel 2. Tabulasi Silang Solusi Cluster Setelah Penukaran Posisi Kolom

\begin{tabular}{|c|c|c|c|c|}
\hline Solusi 1,2 & cluster 1 & cluster 2 & cluster 3 & Total \\
\hline cluster 1 & 3 & 0 & 0 & 3 \\
\hline cluster 2 & 0 & 2 & 0 & 2 \\
\hline cluster 3 & 0 & 0 & 0 & 2 \\
\hline Total & 3 & 2 & 2 & 7 \\
\hline
\end{tabular}

(2) Menghitung nilai

$$
R_{i j}=\text { jumlah diagonal/jumlah objek. }
$$

Sebagai contoh jumlah objek yang konsisten berada pada cluster tertentu pada solusi cluster 1 dan solusi cluster 2 adalah $(3+2+2=7)$ dan nilai reproducibility berpasangan solusi cluster 1 dan solusi cluster 2 adalah 1 .

(3) Menetukan nilai reproducibility total solusi cluster ke-i dengan cara sebagai berikut:

$$
R_{i}=\frac{\left(R_{i 1}+R_{i 2}+\cdots+R_{i j}\right)}{j} .
$$

Sebagai contoh untuk mengetahui nilai reproducibility total solusi cluster 1 maka perlu dihitung nilai reproducibility solusi cluster 1 dan solusi cluster 2 sehingga diperoleh nilai reproducibility total solusi cluster 1 sebesar:

$$
R_{1}=\frac{\left(R_{12}+R_{13}\right)}{2}
$$


Nilai reproducibility dihitung untuk membandingkan solusi dengan jumlah cluster yang sama. Untuk membandingkan solusi dengan jumlah yang berbeda, dilakukan penyesuaian terhadap reproducibility ini, yang dirumuskan sebagai:

$$
R A=\frac{(k R)-1}{k-1} .
$$

\section{Metodologi}

\subsection{Data}

Data yang digunakan pada penelitian ini adalah data indikator kesehatan lingkungan dari seluruh provinsi Indonesia tahun 2016. Data tersebut diperoleh dari Kementrian Kesehatan Republik Indonesia, yang meliputi 34 provinsi dan 8 peubah berskala numerik. Daftar peubah ditampilkan pada Tabel 3.

Tabel 3. Daftar peubah Penelitian

\begin{tabular}{|c|c|}
\hline Peubah & Keterangan \\
\hline X1 & Persentase jumlah desa/kelurahan yang melaksanakan sanitasi total berbasis masyarakat \\
\hline X2 & Persentase kabupaten/kota yang menyelenggarakan tatanan kawasan sehat \\
\hline X3 & Persentase rumah tangga menurut sumber air minum layak \\
\hline X4 & Persentase rumah tangga yang memliki akses terhadap sanitasi layak menurut provinsi \\
\hline X5 & Persentase tempat-tempat umum (TTU) yang memenuhi syarat kesehatan \\
\hline X6 & Persentase tempat pengelolaan makanan (TPM) yang memenuhi syarat kesehatan \\
\hline X7 & Persentase rumah tangga yang menempati rumah layak huni menurut provinsi \\
\hline X8 & Persentase rumah tangga kumuh menurut provinsi \\
\hline
\end{tabular}

\subsection{Analisis Data}

Langkah-langkah analisis data pada penelitian ini adalah sebagai berikut:

(1) Melakukan eksplorasi data untuk melihat gambaran umum mengenai kesehatan lingkungan di Indonesia.

(2) Membentuk anggota ensemble dengan cara mengelompokkan data dengan menggunakan berbagai metode pengklasteran (metode hirarki dan tak berhirarki), dengan berbagai metode perbaikan jarak dan pentuan pusat cluster awal serta dengan berbagai jumlah cluster. Beberapa metode yang digunakan adalah:

(a) Metode cluster berhirarki dengan metode pautan rataan sebagai metode perbaikan jarak.

(b) Metode cluster berhirarki dengan metode pautan lengkap sebagai metode perbaikan jarak.

(c) Metode cluster tak berhirarki dengan metode Distance Based Starting Point untuk menentukan $k$ titik pusat awal.

(d) Metode cluster tak berhirarki dengan metode Density Based Starting Point untuk menentukan $k$ titik pusat awal. 
(e) Metode cluster tak berhirarki dengan metode Hierarchical Starting Point untuk menentukan $k$ titik pusat awal.

(3) Untuk kumpulan solusi yang mengandung dua cluster lakukan:

(a) Dari berbagai solusi yang diperoleh, dihitung nilai reproducibility dan ditentukan solusi terbaik sementara dengan 2, 3, dan 4 cluster. Solusi terbaik inilah yang akan menjadi acuan pemberhentian metode pengklasteran pada tahap sebelumnya.

(b) Mentransformasikan anggota ensemble ke dalam bentuk matriks indikator.

(c) Cluster on clustering, yakni mengelompokkan kembali objek berdasarkan kolom-kolom pada matriks indikator. Pengklasteran dilakukan dengan menggunakan metode $\mathrm{k}$-means dengan berbagai metode pemilihan titik pusat cluster awal dengan berbagai jumlah cluster.

(d) Hitung kembali nilai reproducibility dari setiap solusi yang diperoleh, solusi dengan nilai textitreproducibility tertinggi adalah solusi terbaik sementara yang dapat diambil.

(e) Bila solusi yang diperoleh pada tahap d sama dengan solusi terbaik sementara yang diperoleh pada tahap sebelumnya, maka metode pengklasteran cluster ensemble dihentikan. Jika tidak, lakukan kembali langkah b dan c hingga tidak terjadi perubahan keanggotaan cluster dan solusi sebelumnya dijadikan solusi akhir cluster.

(4) Lakukan langkah 3 untuk kumpulan solusi dengan 3 dan 4 cluster

(5) Lakukan perhitungan reproducibility adjusted untuk memilih solusi cluster mana yang paling baik sebagai solusi akhir consensus.

\section{Hasil dan Pembahasan}

\subsection{Hasil Pengelompokan dengan Cluster Ensemble}

(a) Solusi 2 cluster

Solusi dua cluster yang akan dibentuk dari 34 objek pengamatan terhadap 8 peubah, dimana 34 objek tersebut akan menghasilkan 3 cluster, 22 provinsi pada cluster 1 , dan 12 provinsi pada cluster 2 . Nilai reproducibility pada solusi 2 cluster adalah 0,97, hal ini menunjukkan bahwa terdapat 97\% dari seluruh provinsi di Indonesia yang konsisten berada dalam cluster tertentu untuk seluruh solusi.

(b) Solusi 3 cluster

Solusi tiga cluster yang akan dibentuk dari 34 objek pengamatan terhadap 8 peubah, dimana 34 objek tersebut akan menghasilkan cluster 1 , cluster 2 , dan cluster 3 . Solusi consensus dengan 3 cluster ini menghasilkan 16 provinsi pada cluster 1,10 provinsi pada cluster 2 , dan 8 provinsi pada cluster 3 . Nilai reproducibility pada solusi 3 cluster adalah 0,88 , hal ini menunjukkan bahwa terdapat $88,1 \%$ dari seluruh provinsi di Indonesia yang konsisten berada dalam cluster tertentu untuk seluruh solusi.

(c) Solusi 4 cluster

Solusi empat cluster yang akan dibentuk dari 34 objek pengamatan terhadap 
8 peubah, dimana 34 objek tersebut akan menghasilkan cluster 1 , cluster 2 , cluster 3, dan cluster 4 . cluster 1 terdiri dari 18 anggota cluster, cluster 2 terdiri dari 9 anggota cluster, cluster 3 terdiri dari 4 anggota cluster, dan cluster 4 terdiri dari 3 anggota cluster. Nilai reproducibility pada solusi 4 cluster adalah 0,77, hal ini menunjukkan bahwa terdapat 77,0\% dari seluruh provinsi di Indonesia yang konsisten berada dalam cluster tertentu untuk seluruh solusi.

Nilai reproducibility adjusted yang diperoleh solusi pengklasteran terbaik adalah solusi dengan dua cluster, karena memiliki nilai reproducibility adjusted yang paling tinggi.

\section{Kesimpulan}

Penerapan analisis cluster ensemble untuk mengelompokkan provinsi di Indonesia dilakukan berdasarkan delapan peubah indikator kesehatan lingkungan. Dalam proses pengklasteran objek ke dalam 2, 3, dan 4 cluster, hasil analisis diperoleh nilai reproducibility adjusted sebesar 0,94 untuk solusi 2 cluster, 0,82 untuk solusi 3 cluster, dan 0,69 untuk solusi 4 cluster. Dapat disimpulkan bahwa dari nilai reproducibility adjusted yang diperoleh solusi pengklasteran terbaik adalah solusi dengan 2 cluster, dimana anggota dari cluster 1 merupakan provinsi dengan lingkungan sehat yang lebih baik dibandingkan anggota dari cluster 2 .

\section{Daftar Pustaka}

[1] Iam-on N, Garret S. 2010. LinkCluE: A MATLAB Package for Link- Based Cluster Ensemble Journal of Statistical Software. 36(9): 1 - 3

[2] Johson R.A, and D. W Winchern. 2007. Applied Multivariate Statistical Analysis. New Jersey, Prentice Hall

[3] Kementrian Kesehatan Republik Indonesia.2016. Profil Kesehatan Indonesia Tahun 2016. Kementrian Kesehatan Republik Indonesia, Jakarta

[4] Mattjik A.A, Sumertajaya IM. 2011. Sidik Peubah Ganda dengan Menggunakan SAS. Wibawa GNA, Hadi AF, editor. Bogor (ID):IPB Press

[5] Orme,B. dan Johsons,R.2008. Improving K-Means Cluster Analysis : Ensemble Analysis Instead of Highest Reproducibility Replicates. Sawtooth software

[6] Pokok-Pokok Hasil RISKESDAS 2013. http://terbitan.litbang.depkes.go.id. (24 Februari 2016).

[7] Rachmatin D. 2014. Aplikasi metode-metode agglomerative dalam analisis klaster pada data tingkat polusi udara. Jurnal Ilmiah Program Studi Matematika STKIP Siliwangi Bandung. 3(2): 133 - 149

[8] Report of WHO Technical Consultation. WHO/CDS/RBM/2001.35. Geneva, WHO 2001

[9] Strehl A, Gosh J. 2012. A Knowledge Reuse Framework for Combining Partitionings. The Journal of Machine learning Research. 3(1): 583 - 586 